\title{
ÁNGEL LOOCHKARTT
}

Juan Gustavo Cobo Borda

\section{RESUMEN:}

El escritor y poeta Juan Gustavo Cobo Borda, presenta un perfil del pintor barranquillero Ángel Loochkartt. En un íntimo recorrido por su obra, Cobo interpreta la particular manera en la que el pintor plasma el colorido y la atmósfera del Caribe colombiano. El autor concibe al Carnaval de Barranquilla como la materia prima que permite a Loochkartt construir una metáfora visual de la región.

\section{PALABRAS CLAVE:}

Expresionismo colombiano, pintura del Caribe, Carnaval de Barranquilla, pintores colombianos

\section{ABSTRACT:}

Writer and poet, Juan Gustavo Cobo Borda, presents a profile of Barranquilla painter, Ángel Loochkartt. In an intimate tour through his work, Cobo interprets the particular way in which the painter reflects the color and atmosphere of the Colombian Caribbean. The author sees the Carnaval de Barranquilla as the material that allows Loochkartt to construct a visual metaphor of the region. .

\section{KEYWORDS:}

Colombian expressionism, Caribbean painting, Carnaval de Barranquilla, Colombian painters.
Ángel Loochkartt tiene en la mirada el mismo grado de locura que otro holandés errante: Vicente van Gogh. Si a esto le añadimos varios grados más de temperatura anímica, al haber nacido en Barranquilla, tendríamos un preocupante cuadro clínico. Afortunadamente él canalizó esta intensidad visionaria hacia la pintura y se instaló en el barrio de La Candelaria en Bogotá.

Pero ese preservado Edén colonial, con sus beatas, templos y leyendas de apareci- dos y fantasmas como el pintor Gregorio Vásquez y Ceballos, no respira ya el sueño congelado de la historia. Universidades, centros culturales, lugares de cena y rumba, lo dotan ahora de nerviosa vivacidad; de colores que no son sólo el consabido muro blanco con tejas rojas. A ello, de seguro, contribuyó el activo desasosiego de Loochkartt. Su hermosa casa en azules, de patio y zarzo, de pájaros en jaula y árboles frutales se desdobla en un estudio situado al 
otro lado de la calle, donde el harén mental de sus fantasías se despliega con avidez y garra.

Le gustan las vastas telas para saturarlas de colores fuertes. Incluso más que colores: materia aplicada con brochazos de espátula y que en circulares trazos abren en el telón un espacio. Allí ondulan las sensuales
Le gustan las vastas telas para colores fuertes. Incluso más que colores:

materia aplicada con brochazos de espátula y que en circulares trazos abren en el telón un espacio. Allí ondulan las sensuales Ángelas de sus sueños inalcanzables $y$ prohibidos. saturarlas de Ángelas de sus sueños inalcanzables y prohibidos. Algunas fotos, casi clandestinas, nos revelan jóvenes modelos, muy reales, pero sus ojos de sátiro se han purificado con el alcohol y la trementina. Han visto la flotante pareja de amantes que Oscar Kokoschka puso a volar en su agitado cielo expresionista. Y vivió, también, el replanteamiento italiano con que la trasvanguardia volvió sobre la figura humana. Sólo que él, en verdad, es un neofigurativo: exasperación obsesiva de la disección y la furia creativa misma.

Alvaro Medina, en su libro El Arte del

\section{Juan Gustavo Cobo Borda}

(Asesor Editorial)

Juan Gustavo Cobo Borda, poeta y ensayista bogotano. Fue director durante una década (1973-1984) de la revista Eco de la librería Buchholz, y Gaceta, del Instituto Colombiano de Cultura. Ha ocupado cargos diplomáticos en Buenos Aires y Madrid y fue embajador en Grecia. Miembro número de la Academia Colombiana de la Lengua desde 1993, correspondiente, de la Academia Española ha sido jurado tres veces del Premio Juan Rulfo, (Guadalajara, México); del Rómulo Gallegos, (Caracas); del Reina Sofía de poesía iberoamericana (Madrid), del Neustad, Universidad de Oklahoma, Estados Unidos. Y en 2009 del premio Pablo Neruda, en Santiago de Chile. Ha colaborado con otras publicaciones, como Plural, de México, ABC, de España, y El Nacional de Venezuela.

Entre sus poemarios figuran Consejos para sobrevivir (1974); Todos los poetas son santos (1987); Dibujos hechos al azar de lugares que cruzaron mis ojos (1991) y La musa inclemente (2001) su más reciente libro de poemas es La Patria Boba publicado por Editorial Norma en el 2008. Otras publicaciones recientes son Lengua Erótica: antología poética para hacer el amor (Bogotá: Villegas Editores, 2004), Lector impenitente y El olvidado arte de leer.
Caribe colombiano (2000), escribió: "Fue con una pintura de trazos nerviosos convertidos en rápida acumulación de grafismos como Loochkartt ganó, con El ángel nos llama, uno de los premios del salón de 1986. La obra pertenece a una serie de ángeles nocturnos de aspecto sensual y aura erótica, casi obscena a veces, que ha venido pintando a lo largo de los años y que ha alternado con los festivos congos del Carnaval de Barranquilla, series que combinan las alegrías del alma y los placeres de la carne” (pág. 74).

Durante más de 150 años el Carnaval de Barranquilla se ha constituido en la más afortunada síntesis del mestizaje costeño, al preservar en una ciudad que no fue colonial, todas las tradiciones típicas de blancos, negros e indios. Los cuatro días del carnaval y sus personajes emblemáticos, Joselito Carnaval, la leyenda del hombre caimán, ya habían suscitado la respuesta creativa de figuras como Alejandro Obregón. Ahora Ángel Loochkartt se ha fijado en la danza más antigua del Carnaval de Barranquilla, creada en 1870, con acompañamiento de tambores y guacharacas, y el canto de conocidos versadores. Hasta 120 congos desfilan en nuestros días y Diego Samper Martínez en Carnaval Caribe (1994) los describe así:

Allí están los congos que, conjuntamente con las cumbias, son los reyes del carnaval. Son danzas con reminiscencias de los cabildos negros de la Cartagena colonial [...]. Los danzantes llevan la cabeza cubierta con un alto gorro o turbante elaborado en cartón, adornado con rosas, con flequillos o figuras en papel multicolor. Una penca larga adornada con cintas o pañuelos dispuestos en forma de mariposas, sale del turbante de esta vestimenta [...]. De allí surgen los rostros pintados de blanco con redondas mejillas coloreadas y lentes oscuros [...]. Lo fastuoso 
de la capa, la pechera y el turbante evocan el atuendo usado por los portugueses de la época en sus colonias africanas (pág. 179).

Con su intuición artística Loochkartt captó muy bien el contraste entre los altos y rígidos gorros, con sus, en ocasiones, pompones de lana multicolores, y el vértigo dionisíaco de una danza de negros, ebria e impugnadora. Quizás por ello sus cuadros brotan más de la sombra vencida de la muerte que de la luz de lentejuelas y sol caribe. El congo puede llevar, ¡oh sorpresa!, una iguana viva en la mano y también ponerse máscaras de madera de animal, de tigre o toro, y cetro o machete. Pero lo que importa es cómo Loochkartt mantuvo su altivez ceremonial y su irrupción, desde un mítico sustrato ancestral, en el espacio de sus poderosos óleos, irrigados de sensualidad y fuerza vital. El colorido cinematográfico de las comparsas y la música aturdidora de la guachafita se volvieron el silencio de una pintura, exultante y a la vez reflexiva. Varias décadas antes de que el carnaval fuese consagrado como patrimonio cultural de la humanidad, un pintor bohemio había extraído, en imágenes de celebración plástica, su contagioso ritmo. Su capacidad para servir de metáfora a sus gentes y su región. Se compenetró con su carga legendaria y la tornó plenamente contemporánea.

Después del vuelo de sus Ángelas eróticas y de la transgresión carnavalesca de sus congos, Angel Loockhartt se sumió en una profunda reflexión sobre los alcances de su pintura. Como el convivir mucho tiempo con ciertos temas y obsesiones requería de rupturas y cambios para encontrar de nuevo el placer de la aventura, lo halló “ Bajo la piel de la tierra” recordó sus muchos años viviendo en Villa de Leyva, tierra desértica que ha preservado innumerables fósiles y donde la geología incita a explorar esa nocturna profundidad en tantos casos invisible a los ojos.

Por ello, fue desligándose de las fidelidades figurativas para entregarse a la libérrima exploración de una abstracción que podía ir hasta la más ancestral capa jurásica, con sus restos de siluetas de peces fijados ya de forma indeleble a la roca. Y finalmente, sin ninguna referencia realista, viendo con sorpresa de arqueólogo explorador todas las asociaciones que los colores subterráneos establecen entre sí. Libres y a la vez opacos, sueltos y al mismo tiempo enhebrando sus estructuras; Loockhartt decidió usar la más variada e inimaginable sucesión de soportes en tamaño y en fondos y texturas. Vamos desde cuadros convencionales hasta diminutos retablos y desde rectángulos hasta cubos y cilindros cuya base puede ser el papel amate, los cartones industriales, el lienzo, el lino, el cartón paja, el papel abrasivo, el balso o la madera maciza. Se ha vuelto así un creador que investiga en su materia y que logra un pentagrama no muy distante de la música.

Mediante el arte de la sinestesia hace del color un sonido y de su perpetua atención a músicos como Bartók, Mendelssohn, Dimitri Shostakóvich logra abrir las puertas de nuestra percepción hacia mundos inexplorados que descienden a nuestras raíces más ocultas, pero que no por ello dejan de obligarnos a mirar el vuelo de las constelaciones.

Con sus blancos trazos y sus dorados reflejos ello quedó fijado en la gran exposición que de mayo a julio del 2009 inauguró en el complejo cultural La Localidad de Usaquén.
Loochkartt mantuvo su altivez ceremonialy su irrupción, desde un mítico sustrato ancestral, en el espacio de sus poderosos óleos, irrigados de sensualidad $y$ fuerza vital. 